\title{
Fungal Remediation and Subsequent Methanogenic Digestion of Sixteen Winery Wastewaters
}

\author{
P.J. Strong
}

Scion, Private Bag 3020, Rotorua, 3046, New Zealand; and Department of Biochemistry, Microbiology and Biotechnology, Rhodes University, PO Box 94, Grahamstown 6140, South Africa

Submitted for publication: May 2008

Accepted for publication: September 2008

Key words: Aerobic; cellar; effluent; polyphenol; laccase; vinasse

\begin{abstract}
Sixteen winery wastewaters were partially characterised during peak wine production. Raw wastewaters were inoculated with Trametes pubescens MB 89 to establish whether a submerged culture could be used to treat winery wastewaters, and whether fungally-treated wastewater would be rendered more degradable by secondary biological treatment using methanogenic bacteria. Additionally, laccase activity was monitored during the treatment to determine if phenolic compounds present in the wastewater would stimulate the synthesis of the fungal enzyme. Fungal treatment using T. pubescens MB 89 lowered the chemical oxygen demand (COD) and increased the acidic $\mathrm{pH}$ values of all wastewater samples. Five of the wastewater samples showed an increase in laccase synthesis, but the concentrations were low and did not relate to any individual characteristic that was assayed for. It proved advantageous to methanogenic digestion to fungally pretreat samples that had higher initial phenolic compound and colour concentrations, but disadvantageous for wastewaters with low initial phenolic compound and colour concentrations. Anaerobic digestion of fungally-treated and raw samples generally showed little difference with regard to total COD removal and final $\mathrm{pH}$. The incorporation of white-rot fungus into a pretreatment process such as a jet loop reactor or rotating biological disc contactor could prove to be highly advantageous to cellar wastewater treatment.
\end{abstract}

Global wine production in 2000 was approximately $2.65 \times 10^{10}$ L (Petruccioli et al., 2000). The production of wine yields an equivalent, or even larger, amount of wastewater resulting from various washing operations during the crushing and pressing of grapes, as well as from the rinsing of fermentation tanks, barrels and other equipment or surfaces (Malandra et al., 2003). These wastewaters have large seasonal fluctuations in volume and composition, and vary according to the wine produced and the stage of production (vintage, racking and bottling). Winery wastewater typically has a chemical oxygen demand (COD) of 0.8 to 12.8 $\mathrm{g} / \mathrm{L}$ and an acidic $\mathrm{pH}$ of between 3 and 4 (Petruccioli et al., 2000), although the COD can increase to $25 \mathrm{~g} / \mathrm{L}$ depending on the harvest load and processing activities. Wastewater that is discharged into the environment should have a $\mathrm{pH}$ of 5.5 to 7.5 and a COD below $75 \mathrm{mg} / \mathrm{L}$ (South African Water Act No. 36, 1998), but is frequently discarded with little, if any, treatment (Malandra et al., 2003). Winery wastewater generated mainly from the equipment and bottle washing waters and the cooling processes is generally not toxic or hazardous (Petruccioli et al., 2002), but certain cleaning and sanitising chemicals, such as chlorine and ammonia solvents, are toxic and hazardous to the environment and to biological wastewater treatment systems. Some wineries now use more benign cleaning and sanitising agents, such as hydrogen peroxide, ozone or steam, which have an additional advantage in that less rinsing water is required to remove the chemicals (Musee et al., 2005).

Although waste minimisation is slowly being adopted in the wine industry, its full potential has yet to be realised. Many of the waste minimisation attempts have proven to be inefficient as a result of being carried out in an ad hoc fashion. The primary reason for this inefficiency has been attributed to the lack of a systematic methodology of targeting specific waste streams (Musee et al., 2005). An increasing trend with wineries in urban areas is the pre-treatment of wastewater prior to channelling it into local municipal wastewater treatment facilities. Generally, suspended solids are removed by filtration and sedimentation and the $\mathrm{pH}$ is elevated chemically to facilitate aerobic or anaerobic digestion. This decreases municipal penalties incurred as a result of the acid $\mathrm{pH}$ and high COD. Rural wineries often dispose of their wastewater by irrigation, as they have available space and low population densities. According to a survey conducted by Sheridan et al. (2005), $60 \%$ of South African wineries disposed of their wastewaters by irrigation, $10 \%$ discharge it into municipal drains, $10 \%$ rely on evaporation and $7 \%$ use French drains. The remaining 10\% treat their wastewaters using dams, storage dams, wastewater treatment plants, river discharge or other, unspecified means.

Most municipal activated sludge plants located in wineproducing regions suffer a drastic increase in organic load during the grape harvest period, which often results in problems with biological treatment systems, such as decreased ability of sludge to settle, sludge floc disintegration, increased suspended solids in treated wastewater and, in the worst case, complete process failure (Chudoba \& Pujol, 1996). Brucculeri et al. (2005) studied co-treatment of municipal and winery wastewaters in a full-scale conventional activated sludge process. The wastewater treatment

Corresponding author: e-mail: PJStrong@gmail.com [Tel: +64 07343 5744, Fax: +64 073435528$]$

Acknowledgements: The author is grateful to all the wineries that allowed sampling of their wastewater, and to J.E. Burgess for comments regarding the manuscript. The author acknowledges funding from the National Research Foundation (NRF) of South Africa via a Department of Labour (DoL) Scarce Skills Scholarship. Opinions expressed and conclusions drawn are those of the authors and are not to be attributed to the DoL or NRF. 
plant obtained 90\% COD and 60\% nitrogen removal efficiencies for both an extended oxidation process during vintage (four months per year) and a pre-denitrification/oxidation process during the rest of the year. Good removal efficiencies have been observed with both aerobic and anaerobic biological treatment methods. Petruccioli et al. (2002) lowered the energy used for the aeration of activated sludge by using a jet-loop bioreactor. Anaerobic digestion has been well documented in the literature and has even been used to generate by-products such as biogas. Torrijos and Moletta (1997) found a sequencing batch reactor to be the best option for the treatment of winery wastewater from smaller wineries and obtained more than $90 \%$ removal of total COD, soluble COD and biochemical oxygen demand. Yu et al. (2002) demonstrated continuous hydrogen from the anaerobic acidogenesis of a high-strength rice winery wastewater by mixed bacterial flora in an upflow reactor. Other forms of treatment include evaporation-condensation, ultrafiltration and reverse osmosis (Petruccioli et al., 2000).

White-rot fungi have not been investigated as an alternative to degrade winery wastewaters. White-rot fungi produce enzymes such as laccase, lignin peroxidase and manganese peroxidase, which enable them to degrade lignin and phenolic compounds that are normally toxic to conventional anaerobic treatment systems (Borja et al., 1993). They have shown the ability to remediate wastewaters produced by the food industries (Minussi et al., 2002), the textile industry (Wesenberg et al., 2003) and the paper and pulp industry (Archibald et al., 1997). Fungal treatment has the potential to remediate winery wastewaters and produce laccase as a by-product, which may be utilised in the winemaking process. Laccase has been proposed by Minussi et al. (2007) as an alternative to the physicochemical adsorbents that act on the polyphenols, which are responsible for the madeirisation process in wines. Traditional wine technology has used stabilising procedures such as proteinaceous clarification, polyamides and high doses of sulphur dioxide, which act on catalytic factors, block oxidisers or remove phenolic compounds. Laccase has been shown to react with the phenolic compounds responsible for the antioxidant properties of red wine musts. However, it has shown a higher reduction of the total phenolic compounds than in the total antioxidant potential in white wine musts. Riesling wines that were stable and of high quality have been made using a laccase treatment, showing that product instability could be prevented by using enzymes instead of sulphur dioxide (Maier et al., 1990). Enzymatic treatment has the potential to decrease the costs associated with wine processing and to improve wine stability over long storage times (Cantarelli \& Giovanelli, 1990).

The objectives of this study were to characterise wastewaters from a number of wineries during peak production and then investigate the use of a white-rot fungus to lower the COD, the concentration of phenolic compounds and colour, while increasing the $\mathrm{pH}$ to a level suitable for further treatment by anaerobic digestion. The strain of fungus used in this study (Trametes pubescens MB 89) has previously demonstrated better potential for laccase production and bioremediation than three other fungi when treating wine-distillery wastewater (Strong \& Burgess, 2007). Laccase production during fungal remediation was also assessed, as the wastewater could be utilised as a potential medium in which to produce the enzyme. Fungally-treated wastewater and untreated wastewater were then treated by methanogenic digestion to assess if a fungal pretreatment step was beneficial.

\section{MATERIALS AND METHODS}

Trametes pubescens MB 89 was purchased from Centraalbureau voor Schimmelcultures (The Netherlands, culture 696.94) and routinely subcultured on bacteriological agar (12 g/L, Biolab, Merck Chemicals (Pty) Ltd, Johannesburg) plates containing 2\% malt extract (Biolab, Merck), 1\% glucose (Saarchem, uniLAB, Merck) and $0.2 \%$ yeast extract (Biolab, Merck) and stored at $4^{\circ} \mathrm{C}$. An uncharacterised mixed culture of anaerobes obtained from a winery wastewater methanogenic digester was kindly donated by Dr L. Dekker (Dekker Envirotech, Stellenbosch, South Africa). This culture was stored at $4{ }^{\circ} \mathrm{C}$ and routinely maintained with $2 \%$ Luria broth (Biolab, Merck) in 10\% red wine (Tassenberg), and the $\mathrm{pH}$ was kept above 7.0 with the addition of sodium carbonate powder.

Wastewater was obtained from 15 wineries in the Western Cape Province of South Africa and stored at $4^{\circ} \mathrm{C}$. Aliquots of $65 \mathrm{~mL}$ of unmodified undiluted wastewater were placed in 300 $\mathrm{mL}$ Erlenmeyer flasks, covered with aluminium foil (to prevent contamination) and sterilised by autoclaving for $15 \mathrm{~min}$. Duplicate samples were inoculated with $T$. pubescens MB 89 from stock cultures that had been cultured in a medium containing $2 \%$ malt extract, $1 \%$ glucose and $0.2 \%$ yeast extract (all Merck, Saarchem) and placed on a benchtop shaker (Labcon SP015+UPF75, Maraisburg) at $150 \mathrm{rpm}$ at $28^{\circ} \mathrm{C}$. Control inocula were conducted in duplicate in distilled water to verify the laccase concentration introduced by the inoculum. Samples of $1 \mathrm{~mL}$ were taken in $1.5 \mathrm{~mL}$ Eppendorf containers and centrifuged at $9660 \mathrm{~g}$ for $2 \mathrm{~min}$ (Heraeus Biofuge, Hanau, Germany). The supernatant was aspirated, diluted appropriately and tested for laccase activity, COD concentration, total phenolic compounds concentration, $\mathrm{pH}$ and colour. Samples that did not exhibit laccase synthesis were assayed for seven days, while samples that did were assayed for nine days. Wastewater samples after fungal treatment were combined, centrifuged and $100 \mathrm{ml}$ of the supernatants was placed in $100 \mathrm{ml}$ Erlenmeyer flasks, as was $100 \mathrm{ml}$ of the raw wastewaters. The $\mathrm{pH}$ values were adjusted to between 7.0 and 7.5 and the samples were inoculated with the mixed culture of methanogens while flushing with nitrogen gas to maintain anaerobic conditions. Distilled water served as the control flasks. The flasks were shaken at $50 \mathrm{rpm}$ at $32 \pm 2{ }^{\circ} \mathrm{C}$ for a total of 14 days. Samples of $1.5 \mathrm{~mL}$ were taken and analysed using the same methods as for the fungal samples.

The COD concentration was measured using a colourimetric Spectroquant ${ }^{\circledR}$ method using reagents 14538 and 14539 (Merck) and method number 14541 - analogous to standard method 5220D (Standard Methods, 1998). Laccase activity was measured using a multi-wavelength multi-well plate reader (PowerWave ${ }_{x}$, BioTek Instruments Inc, Winooska, VT, USA) with the oxidation of $0.1 \mathrm{mM} \mathrm{2,2'-azino-di-[3-ethylbenzthiazoline} \mathrm{sulphonate} \mathrm{(6)]}$ diammonium salt (Roche Diagnostics GmbH, Mannheim, Germany) in $100 \mathrm{mM}$ succinic acid (Saarchem, Merck) / lactic acid (Saarchem, Merck) at $\mathrm{pH}$ 4.5. Total phenol concentrations were determined using Folin-Ciocalteus reagent (UN3624, Merck). A $100 \mu \mathrm{L}$ sample was diluted in $1600 \mu \mathrm{L}$ of distilled water and mixed with $250 \mu \mathrm{L}$ of Folin-Ciocalteus reagent for 30 seconds, after which $1500 \mu \mathrm{L}$ of distilled water containing $10 \%$ sodium carbonate was mixed into the solution for $1 \mathrm{~min}$, diluted to $10 \mathrm{~mL}$, and readings were taken after $30 \mathrm{~min}$. The standard curve 
was obtained using pure phenol (Saarchem, univAR, Merck). The concentrations of nitrite, nitrate, ammonia, phosphorus and chloride were all measured using Merck spectroquant kits $1.14776,1.14752,1.14773,1.4543$ and 1.4828 respectively, which are the equivalent of standard methods $4500-\mathrm{NO}_{2}^{-} \mathrm{B}$, $4500-\mathrm{NO}_{3}{ }^{-} \mathrm{E}, 4500-\mathrm{NH}_{3} \mathrm{~F}, 4500-\mathrm{P} \mathrm{C}$ and $4500-\mathrm{Cl} \mathrm{B}$ respectively (APHA et al., 1998). Lactose fermenters were differentiated from non-lactose fermenters on spread plates using McConkey agar (Saarchem, Merck). Electrical conductivity was measured using a Cyberscan Con11 meter (Eutech Instruments). Samples for colour were diluted in $33 \mathrm{mM}$ phosphate-buffered saline at $\mathrm{pH} 7.0$ and measured as an absorbance at $525 \mathrm{~nm}$. Values are displayed as the absorbance at $525 \mathrm{~nm}$ for $1 \mathrm{~cm}$ pathlength $\left(\mathrm{Abs}_{525} / \mathrm{cm}\right)$.

\section{RESULTS AND DISCUSSION}

\section{Wastewater characterisation}

The winery wastewater characteristics are shown in Table 1. The most significant characteristics that would hinder conventional anaerobic biological treatment were the $\mathrm{pH}$ (as acidic as 2.95), the presence of phenolic compounds (up to $95 \mathrm{mg} / \mathrm{L}$ ) and COD values varying from 665 to $12600 \mathrm{mg} / \mathrm{L}$. Malandra et al. (2003) found the composition of winery wastewaters during the 1999 harvest season to be similar to those in this study, having a $\mathrm{pH}$ of between 3.7 and 4.8, total polyphenols of between 0 and 27.2 $\mathrm{mg} / \mathrm{L}$ and a COD of between 320 and $5670 \mathrm{mg} / \mathrm{L}$. The results of this study coincide with those of Malandra et al. (2003) in that a large variation in COD values (and all other parameters tested) was observed. The considerable variation in wastewater constituents can be ascribed to different varieties of grapes, harvest load and operation procedures. The variation in wastewater composition is best illustrated in samples Q and F, which represent two samples from the same winery one day apart. The COD values are more than 10-fold higher on the second day (sample F), and the $\mathrm{pH}$ increased from 2.91 to 4.80 . The COD values and concentrations of total phenolic compounds were generally higher in this study than in the one conducted by Malandra et al. (2003), even though both studies occurred during peak harvest season. This is possibly due to the variations in wastewaters and sampling procedures, but could also reflect the change in practices since 1999. Less wasteful practices regarding water utilisation may be leading to lower volumes of more concentrated wastewaters. Similar variations in results were found by Bustamante et al. (2005), who measured various characteristics of 21 winery and distillery wastewaters. They found that the $\mathrm{pH}$ values ranged from 3.6 to 11.8, polyphenol concentrations from 29 to $474 \mathrm{mg} / \mathrm{L}$, total nitrogen from 0.0 to $142.8 \mathrm{mg} / \mathrm{L}(35.4 \mathrm{mg} / \mathrm{L}$ mean) and phosphorus from 3.3 to 188.3 $\mathrm{mg} / \mathrm{L}$ (35.4 mg/L mean). The values for the phosphorus measured in this study overlapped with the lower end of the range measured by Bustamante et al. (2005), as only soluble phosphorus was measured in the present study. The average electrical conductivity in the present study of $203 \mathrm{mS} / \mathrm{m}$ was very similar to the 190 $\mathrm{mS} / \mathrm{m}$ average obtained by Bustamante et al. (2005), but the range in the present study was greater (64 to $531 \mathrm{mS} / \mathrm{m}$ compared to 80 to $310 \mathrm{mS} / \mathrm{m}$ ).

Many of the winery wastewater samples could only be collected from holding tanks, where degradation may already have occurred as a result of naturally occurring microorganisms. These microorganisms undergo population shifts with time. Jourjon et al. (2005) observed that acetic and lactic acid bacteria and yeasts were dominant in winery wastewater treatment systems at the beginning of the harvest, but progressively diminish during the year until the aerobic microbes become dominant. In addition to naturally occurring microbes, faecal bacteria may also be present. McConkey agar is a useful culture medium that is both selective and differential and is used to determine the presence of faecal coliforms. It contains bile salts and crystal violet, which both

\section{TABLE 1}

Characteristics of winery wastewaters. Total phenols, $\mathrm{COD}, \mathrm{P}, \mathrm{NH}_{3}, \mathrm{NO}_{2}{ }^{-}, \mathrm{NO}_{3}{ }^{-}$and $\mathrm{Cl}^{-}$were measured in $\mathrm{mg} / \mathrm{L}$, colour in absorbance units at $525 \mathrm{~nm} / \mathrm{cm}$ pathlength and electrical conductivity (EC) in $\mathrm{mS} / \mathrm{m}$.

\begin{tabular}{|c|c|c|c|c|c|c|c|c|c|c|c|c|}
\hline $\begin{array}{l}\text { Winery } \\
\text { sample }\end{array}$ & pH & $\begin{array}{c}\text { [Total } \\
\text { phenols ] }\end{array}$ & [COD] & EC & Colour & {$[\mathbf{P}]$} & {$\left[\mathbf{N H}_{3}\right]$} & {$\left[\mathrm{NO}_{2}^{-}\right]$} & {$\left[\mathrm{NO}_{3}^{-}\right]$} & {$\left[\mathrm{Cl}^{-}\right]$} & $\begin{array}{c}\text { Lactose } \\
\text { fermenters }\end{array}$ & $\begin{array}{l}\text { Non-lactose } \\
\text { fermenters }\end{array}$ \\
\hline $\mathrm{A}$ & 3.68 & 85 & 12467 & 2.18 & 20 & 3.59 & 0.04 & 0.28 & 5.6 & 203 & Present & Present \\
\hline B & 4.11 & 95 & 12600 & 1.94 & 13 & 4.28 & 0 & 0.02 & 20.4 & 70 & Present & Present \\
\hline $\mathrm{C}$ & 3.68 & 33 & 11600 & 1.96 & 6 & 4.1 & 0.03 & 0.00 & 17.1 & 170 & - & - \\
\hline $\mathrm{D}$ & 4.22 & 56 & 10067 & 2.22 & 2 & 4.85 & 0.38 & 0.15 & 14.7 & 107 & Present & Present \\
\hline $\mathbf{E}^{*}$ & 4.81 & 27 & 9533 & 5.31 & 4 & 2.1 & 0.03 & 0.06 & 56.2 & 76 & Present & - \\
\hline $\mathrm{F}$ & 4.80 & 7 & 7167 & 3.52 & 5 & 0.01 & 0.00 & 0.02 & 1.4 & 124 & - & Present** \\
\hline $\mathbf{G}^{*}$ & 3.92 & 54 & 6217 & 2.33 & 10 & 4.45 & 0.00 & 0.03 & 0.0 & 203 & - & Present \\
\hline $\mathrm{H}$ & 3.96 & 38 & 5767 & 2.22 & 10 & 5.04 & 0.05 & 0.03 & 3.1 & 162 & Present & - \\
\hline I & 4.44 & 19 & 4583 & 2.75 & 3 & 2.59 & 0.02 & 0.23 & 39.5 & 203 & Present & Present \\
\hline $\mathbf{J}^{*}$ & 4.15 & 32 & 4100 & 1.14 & 3 & 1.35 & 0.05 & 0.03 & 2.2 & 101 & Present & Present \\
\hline $\mathbf{K}^{*}$ & 5.05 & 27 & 3300 & 0.90 & 1 & 3.88 & 0.04 & 0.11 & 6.9 & 39 & Present & Present \\
\hline $\mathrm{L}$ & 4.55 & 16 & 2700 & 1.59 & 1 & 1.41 & 0.03 & 0.04 & 5.1 & 136 & Present & Present \\
\hline $\mathbf{M}^{*}$ & 4.15 & 29 & 2300 & 1.18 & 8 & 2.32 & 0.01 & 0.01 & 82 & 17 & Present & Present \\
\hline $\mathrm{N}$ & 5.03 & 15 & 1767 & 1.82 & 3 & 2.15 & 0.10 & 0.00 & 12.7 & 144 & Present & Present \\
\hline $\mathrm{O}$ & 4.04 & 6 & 1267 & 0.64 & 1 & 0.00 & 0.11 & 0.06 & 0.0 & 151 & Present & - \\
\hline Q & 2.91 & 5 & 667 & 0.84 & 3 & 4.69 & 2.69 & 0.00 & 0.0 & 126 & - & Present** \\
\hline Mean & 4.22 & 34 & 6006 & 2.03 & 6 & 2.9 & 0.22 & 0.07 & 131.1 & 13 & & \\
\hline
\end{tabular}

*Samples that produced laccase during fungal treatment.

**Microbial concentrations were extremely low. 
inhibit gram positive bacteria. The medium also contains peptone and lactose. Lactose fermentation results in a $\mathrm{pH}$ decrease and the bacterial colony is stained red, while peptone fermentation releases ammonia and raises the surrounding $\mathrm{pH}$, resulting in a white or colourless colony. Lactose positive bacteria include Escherichia coli, Klebsiella and Enterobacter spp., while nonlactose-fermenting bacteria include Salmonella, Shigella and Proteus spp. Lactose and non-lactose fermenters were present in the majority of the samples (Table 1).

\section{Chemical oxygen demand}

The raw COD values of the 16 samples varied from 665 to 12 $600 \mathrm{mg} / \mathrm{L}$, with a mean of $6020 \mathrm{mg} / \mathrm{L}$. The COD values of all the wastewater samples were reduced by the fungal treatment (Fig. 1). The average removal efficiency in the eight samples with the highest $\mathrm{COD}$ values (i.e. samples A to $\mathrm{H}$ ) was $84 \%$, while the average removal in the eight samples with the lowest COD values (i.e. samples I to Q) was $45 \%$.
Petruccioli et al. (2002) obtained a slightly higher overall COD efficiency (above 90\%) using a jet-loop, activated sludge reactor over a period of 12 months. The COD values of the wastewater they treated were between 8000 and $12800 \mathrm{mg} / \mathrm{L}$, with COD organic loading rates varying between 0.4 and $5.9 \mathrm{~kg} \mathrm{COD} / \mathrm{m}^{3} / \mathrm{d}$ and a hydraulic retention time of between 2.1 and 4.4 days. The decrease in COD was comparable $(87 \pm 4 \%)$ to the five samples with raw COD values greater than $9000 \mathrm{mg} / \mathrm{L}$. However, the time taken for this digestion in shake-flask cultures was substantially longer (seven days for samples not producing laccase, or nine days for samples that were producing laccase). Increasing the biomass concentration (initially only at $0.85 \mathrm{~g}$ dry mass $/ \mathrm{L}$ ) and providing aeration would considerably reduce the time required to achieve the same level of degradation. Duarte et al. (1997) observed an increase in aeration-improved COD removal. Increased aeration not only enhances the mass transfer of degradable compounds, but increases oxygenation, thereby allowing for the maintenance of greater biomass concentration. However, aeration costs are often

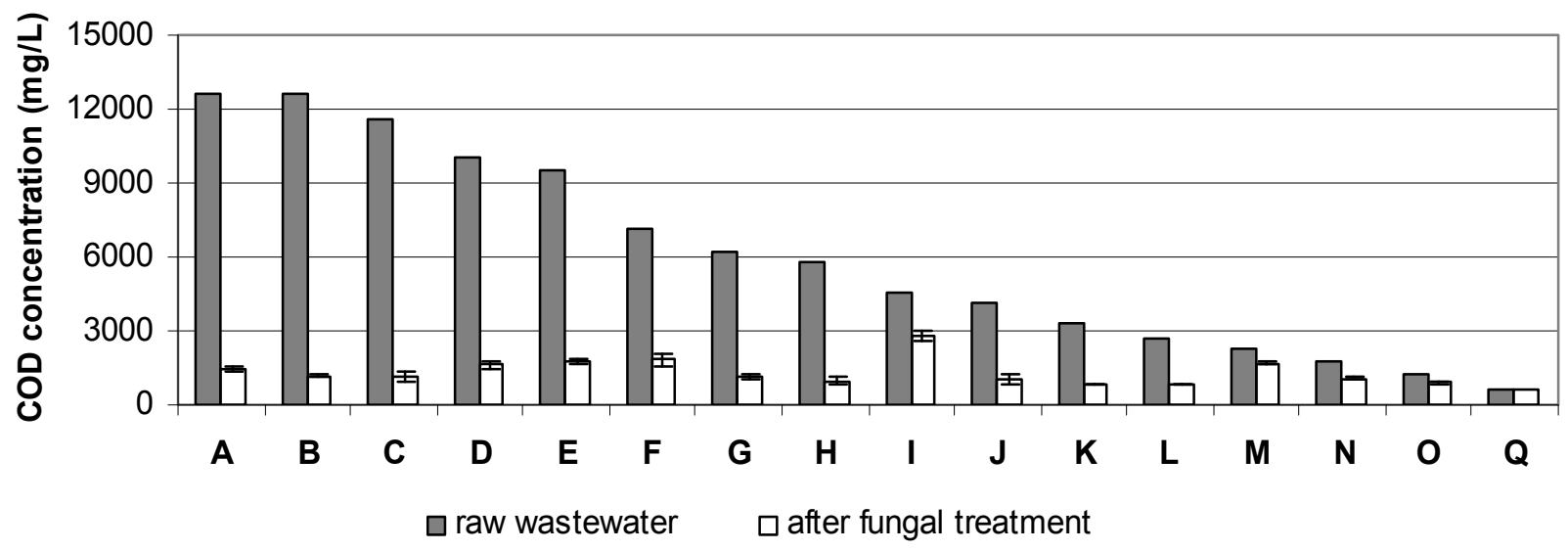

FIGURE 1

Change in COD after fungal treatment (after nine days for samples E, G, J, K and M and after seven days for all the others). Error bars represent standard deviation $(n=2)$.

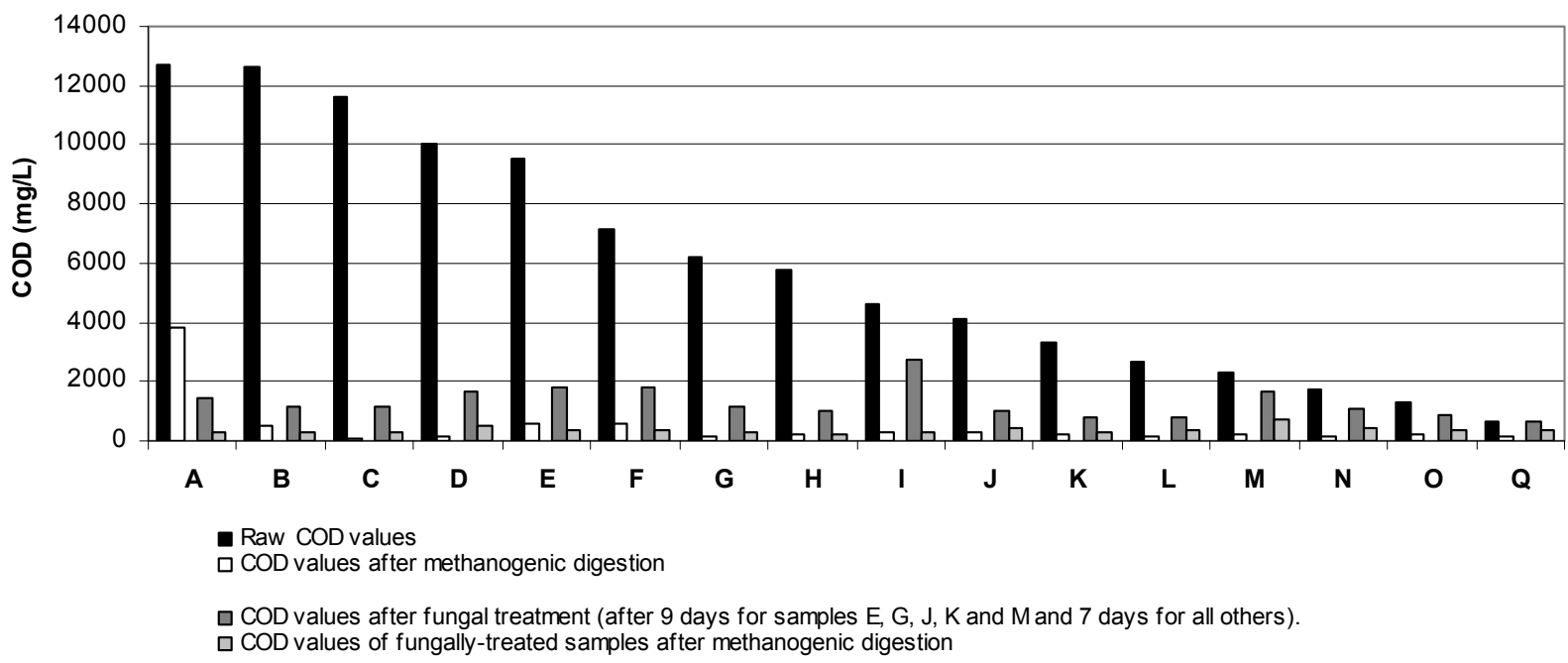

FIGURE 2

Decrease in COD with methanogenic digestion of raw and fungally-treated wastewater. 
expensive, so the benefits must offset the costs of the procedure. Fungal pretreatment does have advantages in that it is often able to treat wastewaters that are toxic to many microorganisms, and valueadded products such as proteins and enzymes may be produced.

The COD concentrations of both the raw and fungally-treated wastewater samples were reduced by treatment with methanogens (Fig. 2). Keyser et al. (2003), evaluating upflow anaerobic sludge blankets for the treatment of winery wastewater, obtained $90 \%$ and $85 \%$ COD removal efficiencies with a 24-hour hydraulic retention time with reactors seeded with granular sludge enriched with Enterobacter sakazakii or with brewery granules respectively. However, they also observed that a reactor seeded with sludge only showed typical problems encountered with conventional sludge seeding and had to be reseeded continuously, as with the flasks in this study. The flasks had to be reseeded with the mixed culture of methanogens after five days, as there was little evidence of gaseous evolution after the second day of treatment.

Pretreatment with fungi prior to methanogenic digestion appeared to offer no distinct advantage with respect to the post-digestion COD concentrations. Although wastewater sample $\mathrm{M}$ was more resistant than the other wastewaters to methanogenic treatment after fungal treatment, there was generally no significant difference in the averaged final COD values between fungally-treated and raw samples. Only the winery samples A (raw) and M (fungally treated) were not degraded by the methanogenic treatment to a final COD concentration of below $600 \mathrm{mg} / \mathrm{L}$. By the end of the anaerobic digestion, the averaged COD concentration was $484 \pm 905 \mathrm{mg} / \mathrm{L}$ for the untreated samples and $359 \pm 118 \mathrm{mg} / \mathrm{L}$ for the fungallytreated samples. If the values for winery wastewater A are omitted, the average COD concentration after methanogenic digestion is $261 \pm 157 \mathrm{mg} / \mathrm{L}$ for the untreated samples and $366 \pm 119 \mathrm{mg} / \mathrm{L}$ for the fungally-treated samples, which is not significantly different.

The data obtained in this study compare well with the data presented by Mulidzi (2006), who used a constructed wetland to treat winery and low-strength distillery waste. An average annual COD removal of 80 to $83 \%$ was obtained with a hydraulic retention time of 14 days. Although the hydraulic retention time was fairly long, constructed wetlands do offer the advantage of being a relatively low-maintenance technology once established, and therefore low cost if the land is available. The treated wastewater in Mulidzi's (2006) study was shown suitable for use for irrigation and used to produce a cash crop in the form of cabbages. However, biological processes are not the only mechanism that can be utilised for winery wastewater remediation. Mosteo et al. (2006) showed that winery wastewaters could be degraded using the photo-Fenton process. Maximum total organic carbon removal of $55 \%$ was achieved for synthetic samples that were prepared by diluting commercial grape juice or red wine in water. However, the time period of the photo-chemical reaction was not given.

\section{Change in pH}

The average initial $\mathrm{pH}$ value of the 16 samples was 4.22 , with values varying from 2.91 to 5.05 . The $\mathrm{pH}$ values of all the raw samples increased as a result of the fungal treatment (Table 2). The average $\mathrm{pH}$ increase of the raw samples A-H was $3.13 \mathrm{pH}$ units, and that for samples I-Q was $2.96 \mathrm{pH}$ units. The average $\mathrm{pH}$ of all the fungally-treated samples was 7.26, which would be advantageous for anaerobic digestion when compared to the original average of 4.22 , as it would not need to be modified prior to treatment.
TABLE 2

$\mathrm{pH}$ values of wastewaters before and after fungal and anaerobic treatment.

\begin{tabular}{ccccc}
\hline Sample & Initial & $\begin{array}{c}\text { After fungal } \\
\text { treatment* }\end{array}$ & $\begin{array}{c}\text { After } \\
\text { fungal and } \\
\text { methanogenic } \\
\text { treatment }\end{array}$ & $\begin{array}{c}\text { After } \\
\text { methanogenic } \\
\text { treatment }\end{array}$ \\
\hline A & 3.68 & 7.40 & 8.05 & 7.71 \\
B & 4.11 & 7.38 & 7.81 & 8.07 \\
C & 3.68 & 6.67 & 8.21 & 8.66 \\
D & 4.22 & 6.73 & 8.34 & 8.28 \\
E & 4.81 & 7.84 & 8.30 & 8.34 \\
F & 4.80 & 7.56 & 7.82 & 8.76 \\
G & 3.92 & 7.33 & 7.74 & 8.44 \\
H & 3.96 & 7.31 & 7.87 & 8.87 \\
\hline I & 4.44 & 6.65 & 7.84 & 8.11 \\
J & 4.15 & 7.49 & 7.88 & 8.03 \\
K & 5.05 & 7.22 & 8.43 & 7.77 \\
L & 4.55 & 7.43 & 8.20 & 7.75 \\
M & 4.15 & 7.25 & 7.63 & 8.66 \\
N & 5.03 & 7.13 & 7.93 & 8.39 \\
O & 4.04 & 7.18 & 8.40 & 6.18 \\
Q & 2.91 & 7.65 & 8.38 & 7.83 \\
\hline
\end{tabular}

*after nine days for samples E, G, J, K and M and after seven days for all the others

The $\mathrm{pH}$ values of all the raw wastewater samples were adjusted to between 7.0 and 7.5 with sodium carbonate in order to facilitate methanogenic digestion. The $\mathrm{pH}$ values of all the samples were adjusted daily over the first seven days of methanogenic digestion using sodium carbonate powder if they fell below 6.5. The greatest daily decreases in $\mathrm{pH}$ occurred in the raw wastewater samples that had higher initial COD values, possibly as a function of greater metabolic activity. By the end of the digestion, the average $\mathrm{pH}$ values were very similar for the raw wastewater samples $(8.12 \pm$ $0.6)$ and the fungally-treated wastewater samples $(8.05 \pm 0.27)$. Duarte et al. (1998) also observed a pH increase with increasing digestion time and attributed it to the metabolic degradation of various acids present in the wastewater.

\section{Degradation of phenolic compounds}

With the fungal treatment, the greatest removal efficiencies of phenolic compounds were obtained with samples that had the highest initial concentrations of total phenolic compounds (Fig. 3 ). The concentration of total phenolic compounds for all but three of the 16 samples decreased to its lowest value after two days of fungal treatment. Laccase degradation of catechins has previously been shown to be very fast, while the degradation of stilbenes (cis and trans resveratrol) and derivatives of cinnamic acids (ferulic and caffeic acid) and benzoic acids (syringic, vanillic and gallic acid) is relatively slow (Minussi et al., 2007). Although laccase and fungal metabolism may have degraded the phenolic compounds present in the wastewater, the fungi themselves may have released phenolic compounds as a result of metabolic activities or with cell autolysis. The concentration of phenolic compounds increased slightly by the end of the fungal treatment, which indicated that a phenolic compound was synthesised during the fungal treatment. This had also occurred with the treatment of distillery wastewaters (Strong \& Burgess, 2007). Eggert et al. (1996) identified a tryp- 


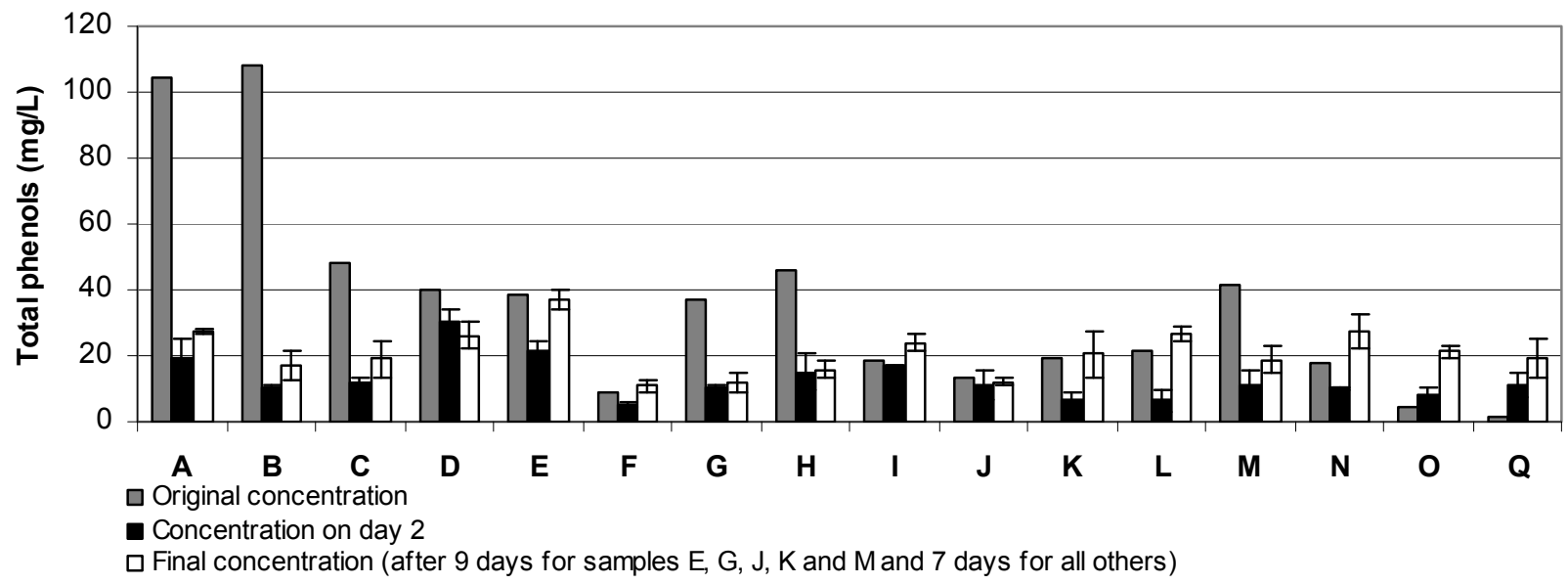

FIGURE 3

Change in concentration of total phenolic compounds with fungal treatment. Error bars represent standard deviation $(n=2)$.

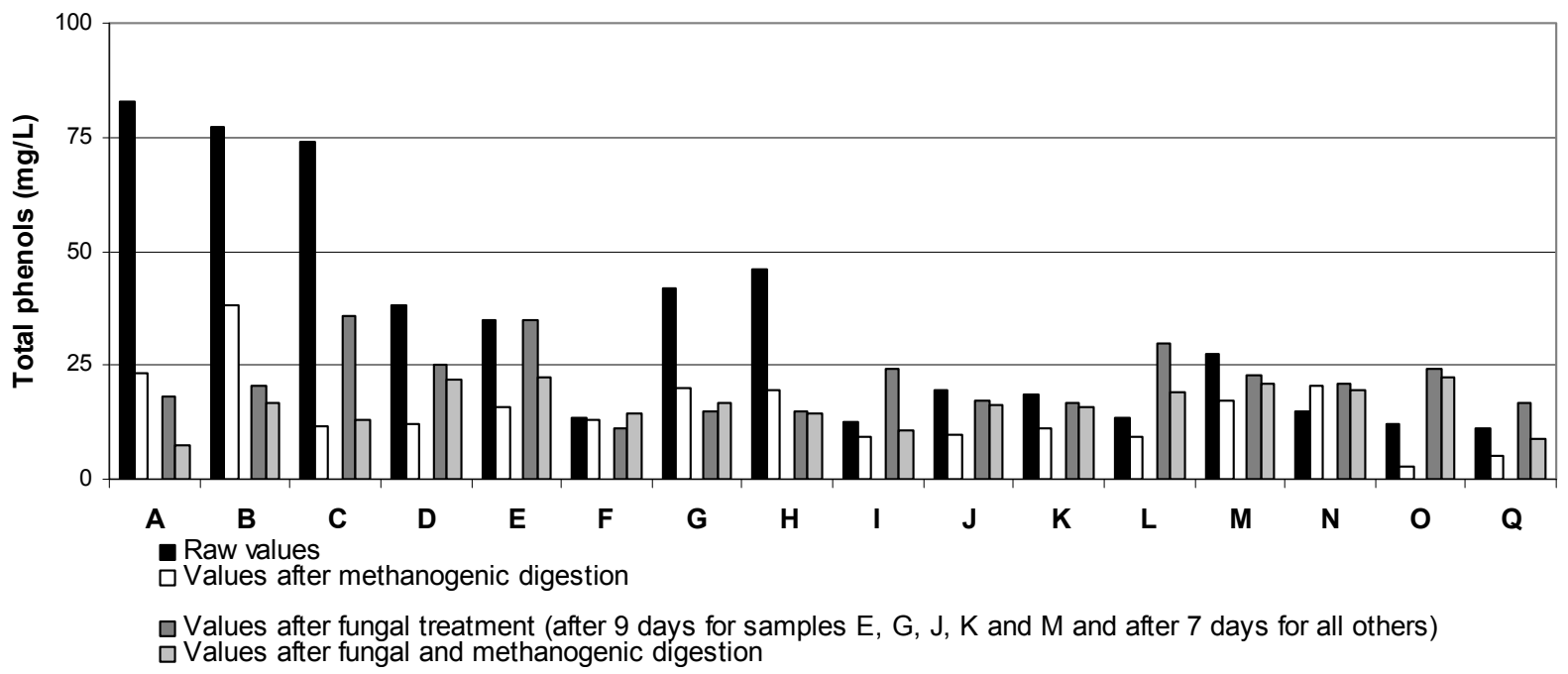

FIGURE 4

Change in concentration of total phenolic compounds with methanogenic digestion of raw and fungally-treated wastewater.

tophan-derived metabolite (3-hydroxyanthranilate) that was secreted by Pycnoporus cinnabarinus, which functioned as a mediator and allowed laccase to oxidise substances with higher oxidation potentials. In the current study, the phenolic compounds were synthesised in low concentrations, but the percentage increase was substantial in wastewater samples that originally had very low phenolic concentrations.

There is a great increase in wastewater volume during the harvest and grape-processing season. Shorter treatment times are a great advantage when peaks occur in wastewater volume. Jiménez et al. (2006) reported that the pretreatment of distillery wastewater with Penicillium decumbens increased the kinetic constant for the subsequent anaerobic digestion process 6.9fold. They attributed the increased degradation efficiency and the reduction in toxicity to the decrease in concentration of phenolic compounds (from 0.450 to $0.145 \mathrm{~g} / \mathrm{L}$ ). Often real wastewaters prove more resistant to treatment than synthetic solutions and conditions. A yeast that was able to completely degrade relatively high concentrations of caffeic acid, vanillic acid, $p$-coumaric acid, gallic acid and catechol was found to be ineffective when treating olive-mill wastewater (Passarinho et al., 1998). This illustrates the complexity of microbial inhibition, which is often not a single factor but due to a synergy of factors such as $\mathrm{pH}$, ionic concentration and phenolic compounds.

Anaerobic digestion removed phenolic compounds from both the raw wastewater and the fungally-treated wastewater. The final removal efficiencies were generally better for anaerobic digestion than for the fungal treatment, as 11 of the anaerobically-treated samples had lower final values. However, when comparing the data used to construct Figs. 3 and 4, it was evident that, for the majority of the samples, the laccase-producing fungi decreased the concentration of phenolic compounds as much in two days as anaerobic digestion did in two weeks. Significantly, six of the fungally-treated samples showed further decreases in phenolic 


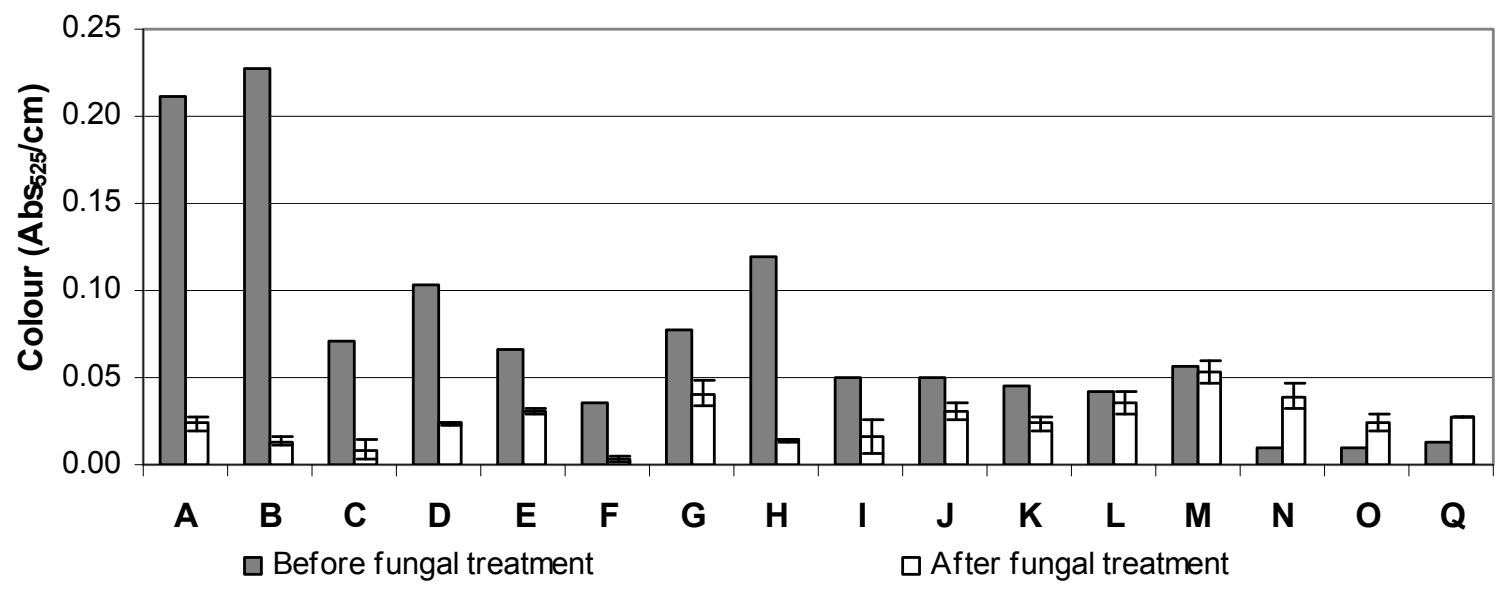

FIGURE 5

Change in colour with fungal treatment (after nine days for samples E, G, J, K and M and seven days for all the others). Error bars represent standard deviation $(n=2)$.

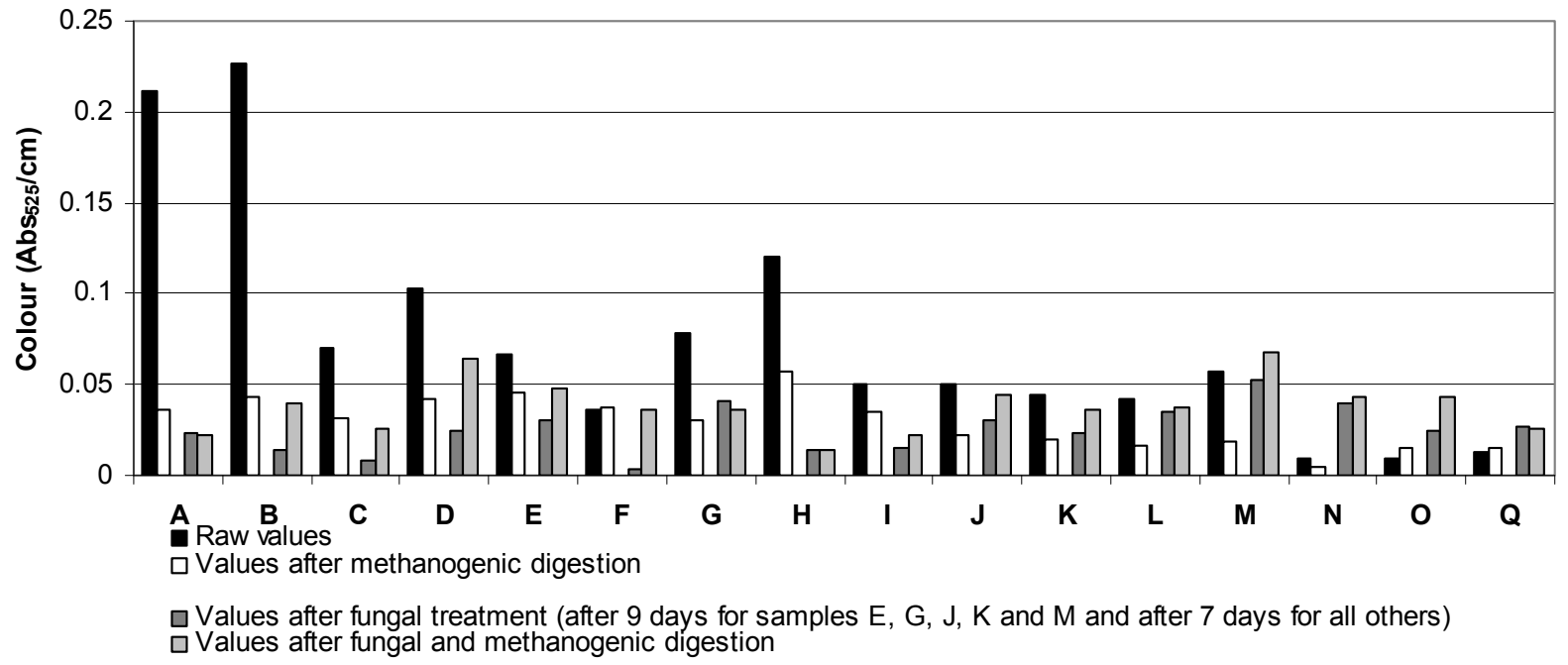

FIGURE 6

Change in colour with methanogenic digestion of raw and fungally-treated wastewaters.

compounds (Fig. 4), indicating that the anaerobic digestion was capable of removing some phenolic compounds that the fungal treatment did not, or that were produced by the fungi themselves.

\section{Change in colour}

The colour decreased as a result of the fungal treatment in all but the three samples that had the lowest initial COD values (Fig. 5 ). The decrease in colour correlated closely with the decrease in phenolic compounds. The decrease in colour was substantial for the two samples with the highest raw concentrations of phenolic compounds (A and B). Various phenolic compounds found in the skin of red grapes are responsible for the red colour of winery wastewaters. The most distinctive is the red to purple colour that is imparted by the anthocyanins (glycosylated anthocyanins). The samples with greater concentrations of phenolic compounds ranged in colour from light purple to light red. It has been observed that the oxidation of certain compounds in wines results in an increase in colour. Somers and Evans (1986) observed that atmospheric oxidation was not necessary for ageing reactions to occur in high and low phenol wines, but in the presence of air the loss of monomeric anthocyanins and the increase in polymeric pigments and chemical ageing were more rapid. They observed an early increase in colour density upon air contact, which gradually declined until the colour densities of aerobic and anaerobic wines were very similar. If these compounds were present in the wastewater, the natural oxidation would result in an increase in colour intensity. Fungal remediation of distillery wastewaters originating from the distillation of wine showed $T$. pubescens capable of degrading the colour-containing compounds such that the wastewater changed from a dark red/purple colour to a light yellow (unpublished data).

The anaerobic digestion decreased the colour markedly for all but two of the 16 raw samples (Fig. 6). The fungally-treated samples all had much lower initial colour absorbance values, which led 


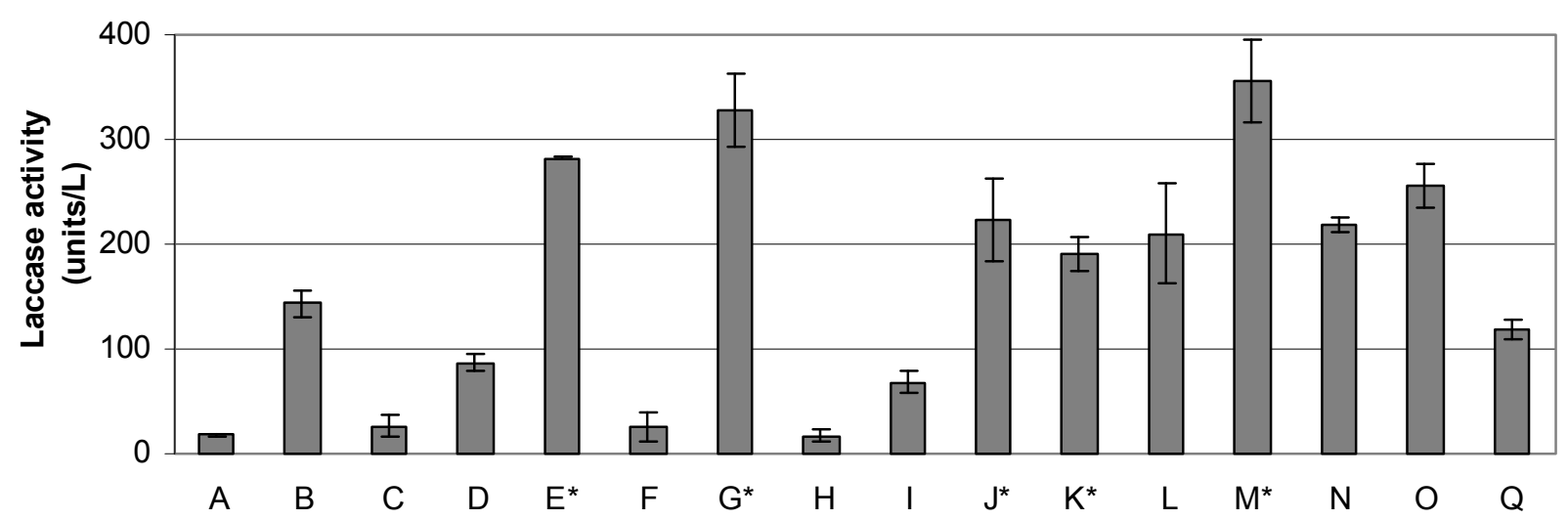

FIGURE 7

Highest laccase activities after nine days for samples E, G, J, K and M and after seven days for all the others. Error bars represent standard deviation ( $n=2)$. ${ }^{\text {indicates }}$ samples that increased in laccase activity.

to less significant decreases being obtained. A recent review by Pant and Adholeya (2007) states that the alcoholic fermentation of molasses results in a wastewater with a large concentration of brown compounds. The brown colour in the molasses distillery wastewater results from phenolic compounds (tannic and humic acids) originating from the feedstock, melanoidins that result from Maillard reaction between sugars (carbohydrates) and proteins (amino groups), caramels from overheated sugars and furfurals from acid hydrolysis. Conventional treatments reduce the colour in these wastewaters minimally and the colour may even be increased during anaerobic treatment (due to repolymerisation of compounds). The colour increased in a number of the samples after anaerobic treatment of the fungally-pretreated wastewaters in the current study. It is possible that some of the compounds that were depolymerised by the fungal treatment were repolymerised during the anaerobic treatment. Most of the samples displayed a slight increase in colour during the digestion, possibly due to the increase in $\mathrm{pH}$.

\section{Laccase synthesis}

Of the 16 wastewater samples inoculated with $T$. pubescens, only five displayed an increase in laccase synthesis. The increase could not be attributed to the initial COD or the concentration of phenolic compounds. The laccase values attained were very low for this particular fungus, the highest being 384 units/L (Fig. 7). The treatment of a brandy distillery wastewater had previously yielded laccase concentrations of $4644 \pm 228$ units/L in shakeflask cultures (Strong \& Burgess, 2007).

The synthesis of laccase in submerged cultures of fungi has been shown to be dependent on factors such as the carbon source, nitrogen source, $\mathrm{pH}$, the presence of inducers such as copper or phenolic compounds, as well as sufficient agitation and oxygen supply. Copper is a vital component of laccase and may have been present in concentrations too low to allow for synthesis of the metalloenzyme. There is a large body of literature showing that various phenolic compounds stimulate the production of fungal enzymes. A number of these enzyme-inducing phenolic compounds are present in wine, notably red wines, and thus should be present in fractions of the cellar wastewaters (Strong $\&$ Burgess, 2008). The lack of laccase synthesis was probably attributable to two primary factors: an insufficient carbon source and an acidic $\mathrm{pH}$. Visible biomass growth was marginal compared to the cell concentrations attained in the inoculum's growth media. Malandra et al. (2003) found that wastewater generated from the destemming and pressing operations contained relatively high concentrations of glucose, fructose and malic acid that originated from the grapes themselves. Unfortunately, dilution from rinsing as well as prior degradation by environmental microorganisms would have lowered the fraction of easily utilisable carbon sources. In addition, wastewater from cellars generally contains a variety of other compounds, salts and cleaning agents, which may hamper growth and laccase synthesis.

\section{CONCLUSIONS}

Winery wastewaters were treatable by a pure culture of Trametes pubescens MB 89, obtaining up to 91\% COD removal efficiency and $90 \%$ removal of total phenolic compounds. The $\mathrm{pH}$ was increased in all samples after fungal treatment, making them more amenable to anaerobic treatment. The colour and concentration of phenolic compounds decreased in wastewater samples with high initial values, while both characteristics increased for samples that had low initial values. Relatively low concentrations of laccase were produced, even though a few of the samples had relatively high COD values for winery wastewaters. Laccase was synthesised in five of the 16 samples, but at low concentrations that could not be related to the parameters assayed for in the characterisation studies.

There appeared to be little advantage for methanogenic digestion by fungally pretreating the winery wastewater with respect to overall COD removal, as the same levels of degradation were obtained using anaerobic digestion of raw and pretreated samples. The technical knowledge and stringent sterility requirements to maintain a monoculture would not be financially viable as an initial treatment step. Further work in this area would require a more robust system that could maintain bioremediation in the presence of various other microorganisms, such as yeasts and 
bacteria. The key to a successful aerobic wastewater pretreatment would lie in a system that utilises immobilised biomass to treat a well-oxygenated or thin layer of wastewater. The incorporation of white-rot fungal mycelia in a rotating biological contactor, such as the one developed by Malandra et al. (2004), may well enable such a technology to withstand perturbations caused by higher phenolic loads. Enzymes secreted by the fungi that degrade phenolic compounds could result in decreased inhibition of other microorganisms. If phenolic compounds do inhibit biological treatment processes such as anaerobic digestion, it could be that an aerobic pretreatment step with immobilised laccase and/or other enzymes may prove a more feasible alternative. However, no such limitation was observed with methanogenic digestion for the majority of the $\mathrm{pH}$-adjusted, raw wastewaters in this study. Other factors that may inhibit anaerobic digestion include disinfectants, sanitisers and inorganic ions. Ideally, these wastewater streams would be separated from the biological treatment stream to allow for optimal biological degradation. Low maintenance technology, such as constructed wetlands followed by use for the irrigation of a non-food crop such as timber trees, or more intensive treatment systems such as methanogenic digestion, which generate a product in the form of biogas, appear to be more viable alternatives for winery wastewater treatment.

\section{LITERATURE CITED}

APHA (American Public Health Association), American Water Works Association \& Water Environment Federation. 1998. Standard methods for the examination of water and wastewater, 20th edition. Washington DC, USA.

Archibald, F.S., Bourbonnais, R., Jurasek L., Paice, M.G. \& Reid, I.D., 1997. Kraft pulp bleaching and delignification by Trametes versicolor. J. Biotechnol. $53,215-236$.

Borja, R., Martfla, A., Maestro, R., Luque, M. \& Durfin, M.M., 1993. Enhancement of the anaerobic digestion of wine distillery wastewater by the removal of phenolic inhibitors. Bioresource Technol. 45, 99-104.

Brucculeri, M., Bolzonella, D., Battistoni, P. \& Cecchi, F., 2005. Treatment of mixed municipal and winery wastewaters in a conventional activated sludge process: a case study. Water Sci. Technol. 51, 89-98.

Bustamante, M.A., Paredes, C., Moral, R., Moreno-Caselles, J., Pérez-Espinosa, A. \& Pérez-Murcia, M.D., 2005. Uses of winery and distillery effluents in agriculture: characterisation of nutrient and hazardous components. Water Sci. Technol. 51, 145-151.

Cantarelli, C. \& Giovanelli, G., 1990. White wine stabilization treatments by enzymic oxidation of polyphenols. Rev. Fres. Oenol. 127, 15-25.

Chudoba, P. \& Pujol, R., 1996. Activated sludge plant facing grape harvest period - a case study. Water Sci. Technol. 34, 25-32.

Duarte, E., Martins, M., Carvalho, E., Costa, S. \& Spranger, I., 1997. An integrated approach for overcoming the environmental impacts of wineries wastewaters in a Portuguese case study. In: Proc. Intern. Symp. Vine and Wine, October 1997, Yangling, China. pp. $1-5$.

Duarte, J.C., Ferreira, A., Eusébio, A., Federici, F., Petruccioli, M., Cicalini, A.R., Spranger, M.I., Carvalho, E., Costa, S., Duarte, E.A. \& Martins, M., 1998. Application of highly aerobic reactors in winery effluent treatment. Development of microbial inocula. In: Mota, M. \& Ferreira, E.C. (eds), Book of abstracts I IberoAmerican Meeting on Biotechnology BIOTEC'98, Guimarães, Portugal. p. 298.

Eggert, C., Temp, U., Dean, J.F.D. \& Eriksson, K-E.L., 1996. A fungal metabolite mediates degradation of non-phenolic lignin structures and synthetic lignin by laccase. FEBS Lett. 391, 144-148.

Jiménez, A.M., Borja, R., Martın, A. \& Raposo, F., 2006. Kinetic analysis of the anaerobic digestion of untreated vinasses and vinasses previously treated with Penicillium decumbens. J. Environ. Manage 80, 303-310.
Jourjon, F., Khaldi, S., Reveillere, M., Thibault, C., Poulard, A., Chretien, P. \& Bednar, J., 2005. Microbiological characterization of winery effluents: an inventory of the sites for different treatment systems. Water Sci. Technol. 51, 19-26.

Keyser, M., Witthuhn, R.C., Ronquest, L.C. \& Britz, T.J., 2003. Treatment of winery effluent with upflow anaerobic sludge blanket (UASB)-granular sludges enriched with Enterobacter sakazakii. Biotechnol. Lett. 25, 1893-1898.

Maier, G., Dietrich, H. \& Wucherpfenning, K., 1990. Winemaking without SO - with the aid of enzymes. Weineirtschaft-Technik 126, 18-22 (Cited in Minussi et al., 2007).

Malandra, L., Wolfaardt, G., Zietsman, A. \& Viljoen-Bloom, M., 2003. Microbiology of a biological contactor for winery wastewater treatment. Water Res. 37, 4125-4134.

Malandra, L., Lovis, K., Coetzee, G., Wolfaardt, G. \& Viljoen-Bloom, M., 2004. Evaluation of a rotating biological contactor for biological treatment of winery effluent. Wineland 2, 68-71.

Minussi, R.C., Pastore, G.M. \& Durán, N., 2002. Potential applications of laccase in the food industry. Trends Food Sci. Technol. 13, 205-216.

Minussi, R.C., Rossi, M., Bologna, L., Rotilio, D., Pastore, G.M. \& Durán, N., 2007. Phenols removal in musts: strategy for wine stabilization by laccase. J. Mol. Catalysis B: Enzymatic 45, 102-107.

Mosteo, R., Ormad, P., Mozas, E., Sarasa, J. \& Ovelleiro, J.L., 2006. Factorial experimental design of winery wastewaters treatment by heterogeneous photoFenton process. Water Res. 40, 1561-1568.

Mulidzi, A.R., 2006. Winery wastewater treatment by constructed wetlands and the use of treated wastewater for cash crop production. Proc. IV Intern. Spec. Conf. Sust. Vit.: Winery Wastes and Ecology Impact Management (Winery 2006), Viña del Mar, Chile. pp. $271-282$

Musee, N., Lorenzen, L. \& Aldrich, C., 2005. Cellar waste minimization in the wine industry: a systems approach. J. Cleaner Prod. 15, 417-431.

Pant, D. \& Adholeya, A., 2007. Biological approaches for treatment of distillery wastewater: a review. Bioresource Technol. 98, 2321-2334.

Passarinho, P.C., Rosa, M.F. \& Vieira, A.M., 1998. Phenols degradation by an olive oil wastewater isolated yeast. In: Mota, M. \& Ferreira, E.C. (eds). Book of abstracts I Ibero-American Meeting on Biotechnology BIOTEC'98, Guimarães. Portugal. p. 298.

Petruccioli, M., Duarte, J.C. \& Federici, F., 2000. High rate aerobic treatment of winery wastewater using bioreactors with free and immobilized activated sludge. J. Biosci. Bioeng. 90, 381-386.

Petruccioli, M., Duarte, J.C., Eusebio, A. \& Federici, F., 2002. Aerobic treatment of winery wastewater using a jet-loop activated sludge reactor. Proc. Biochem. $37,821-829$.

Sheridan, C.M., Bauer, F.F., Burton, S. \& Lorenzen, L., 2005. A critical process analysis of wine production to improve cost, quality and environmental performance. Water Sci. Technol. 51, 39-46.

Somers, T.C. \& Evans, M.E., 1986. Evolution of red wines I. Ambient influences on colour composition during early maturation. Vitis $25,31-39$.

Strong, P.J. \& Burgess, J.E., 2007. Bioremediation of a wine distillery wastewater using white rot fungi and the subsequent production of laccase. Water Sci. Technol. $56,179-186$.

Strong, P.J. \& Burgess, J.E., 2008. Treatment methods for wine-related and distillery wastewaters: a review. Bioremediation J. 12, 70-87.

Torrijos, M. \& Moletta, R., 1997. Winery wastewater depollution by sequencing batch reactor. Water Sci. Technol. 35, 249-257.

Wesenberg, D., Kyriakides, I. \& Agathos, S.N., 2003. White-rot fungi and their enzymes for the treatment of industrial dye effluents. Biotechnol. Adv. 22, 161187.

Yu, H., Zhu, Z., Hu, W. \& Zhang, H., 2002. Hydrogen production from rice winery wastewater in an upflow anaerobic reactor by using mixed anaerobic cultures. Int. J. Hydrogen Energy 27, 1359-1365. 